\title{
¿Primavera chilena?
}

\section{Chilean springtime}

Para los antiguos romanos, octubre era el octavo mes del año, y pese a que el calendario juliano lo transformó en el $\mathrm{X}$, conservó su origen etimológico que representa al VIII. Pero sin duda, el mes de octubre aporta a la historia acontecimientos que marcan un antes y un después: así fueron en occidente 1492, 1917, 1962. En el primero, el descubrimiento del mundo Nuevo, en el segundo, la revolución rusa y el tercero la "así llamada crisis de los misiles de octubre" en el cual -este último- el mundo se asomó al apocalipsis. En nuestro entorno nacional, en los años por venir, sin duda que octubre será considerado, recordado y analizado en forma iterativa para comprender a cabalidad los orígenes, el desarrollo y las repercusiones del movimiento que se inició el 18 de octubre.

El 18 de octubre algo se puso en marcha en nuestro país cambiando las vidas presentes y futuras de generaciones en maneras que aún no comprendemos por completo. Ese "algo" ha sido denominado de múltiples maneras, aunque todas parecen converger en el concepto de "estallido social". En lo que las interpretaciones sí divergen, es en las causas: algunas opiniones ponen el acento en lo histórico-político, otras en lo económico-social, sin estar ausentes quienes no descartan elementos conspirativos en la concreción de los acontecimientos. Todas las opiniones, sin embargo, concuerdan en que difícilmente nuestro país seguirá siendo el mismo.

Lo anterior, incumbe a todas las esferas de nuestra convivencia como país y a todas las actividades, incluyendo muy especialmente las educacionales -universitarias o no-, las relacionadas con la salud y la previsión, todos conceptos atingentes al concepto de"protección social" que pareciera ser la piedra angular de la inquietud y malestar subyacente al conflicto. $\mathrm{O}$ dicho de otra forma, la relación de los individuos con el estado y viceversa, y de los individuos entre sí es lo que está siendo cuestionado y que probablemente requerirá incorporar nuevos análisis y nuevos pensamientos que aporten nuevas luces hacia una mayor estabilidad futura.

Aunque en los últimos 50 años (1969 a 2019) el producto interno bruto en Chile ha aumentado 37 veces (de US 8100 a US 307000 millones de dólares) y el ingreso per cápita (promedio) casi 24 veces ( de US \$872 a US \$ 21190 dólares/año)- según datos del FMl y Banco Mundial- el país mantiene cifras no despreciables de dispersión o diferencias distributivas que parecen estar en la raíz de algunas de las demandas referentes a la protección social subyacentes en el conflicto, como podemos evaluar con algo de detalle en una de las dos cartas al Editor vinculadas a este número, (Valdés, 2019). Esta medida significativa de dispersión para algunos -inequidad para otros- parece ser un factor importante en la retroalimentación de algunos de los conflictos de los individuos con nuestra forma de organizarnos como sociedad. Esto es y será motivo de análisis y reformas políticas que nos afectarán a todos en los años por venir, modificando probablemente límites y equilibrios dados por nuestra Constitución actual y nuestras leyes.

En el corazón de estas demandas parece estar uno de los aspectos más relevantes para la vida de las personas, cual es la salud, en el cual se ha cuestionado el modelo de desarrollo vigente, con una vertiente gubernamental y otra privada, con un rol subsidiario del estado. Sin duda, hay aspectos perfectibles en este modelo que deberán hacerse considerando aspectos técnicos, políticos, epidemiológicos, demográficos y económicos, probablemente en cuanto la crisis haya amainado.

Uno de los aspectos centrales -y probablemente más preocupantes en este conflicto ha sido el comportamiento inusitadamente violento de algunos grupos de ciudadanos, incluyendo actos de destrucción de propiedad pública y privada así como ataques a instituciones, que ha llevado a una polarización acentuada en diversos estamentos de nuestra población. La expresión viva de este comportamiento es la gran cantidad de "graffiti" que ha copado los muros de nuestras principales ciudades. La cantidad de "grafitti" impresiona, pero especialmente el contenido de los mensajes, que trasuntan grietas importantes en nuestra sociedad de las que tendremos que hacernos cargo en el futuro inmediato. 
La interpretación de estos comportamientos particularmente violentos aunque compleja, se profundiza en la segunda Carta al Editor adscrita a este número (Dörr, 2019) con un enfoque antropológico y holístico.

Octubre no ha terminado aún, aunque estamos en diciembre. Solo podemos creer y esperar que los cambios iniciados en los timoneles y el velamen de la política en nuestro país junto a la inspiración de Adviento y Navidad hagan que nuestra barca nacional navegue por aguas de mayor paz y prosperidad, como espera la mayoría de los chilenos.

\section{Dr. Roberto Jalil Milad}

Editor en Jefe

ARS Medica, Revista de Ciencias Médicas

Facultad de Medicina

Pontificia Universidad Católica de Chile

\section{Referencias}

Dorr O. (2019). Reflexiones en torno a la extrema violencia que ha acompañado a la crisis social de Chile. ARS Medica, Revista de Ciencias Médicas 44, 5

Valdés R. (2019). Desigualdad y la primavera chilena. ARS Medica, Revista de Ciencias Médicas 44, 8 